\title{
Energy content, storage substances, and construction and maintenance costs of Mediterranean deciduous leaves
}

\author{
S. Diamantoglou ${ }^{1}$, S. Rhizopoulou ${ }^{1}$, and U. Kull ${ }^{2}$ \\ ${ }^{1}$ Institute of General Botany, University of Athens, Panepistimiopolis GR-15784 Athens, Greece \\ ${ }^{2}$ Biologisches Institut, Universität Stuttgart, D-7000 Stuttgart 80, Federal Republic of Germany
}

Summary. At monthly intervals water content, crude fibre, total and protein nitrogen, sugars, starch, total lipids, ash content and calorific total energy were measured throughout the lifespan of the leaves of the deciduous mediterranean shrubs Pistacia terebinthus L. and Cotinus coggygria Scop. From these data the construction costs and maintenance costs, as well as the construction costs of non-storage compounds and energy expenditure values were calculated. The latter values were also calculated for the evergreen stemmed shrub Ephedra distachya for reasons of comparison with an evergreen mediterranean species. The water status in the deciduous leaves is stable for a long time during the drought period until the beginning of senescence in August/September. In Cotinus an early and considerable increase of storage compounds is found, whilst in Pistacia terebinthus the accumulation is more uniform until August. The $\mathrm{N}$-content is rather low compared with other deciduous leaves, the calorific energy is in the lower range of the values reported for similar species. The construction costs of the leaves of both deciduous species are significantly lower than those calculated by Williams et al. (1987) for two drought deciduous chaparral species but are in agreement with the data reported by other authors on deciduous leaves. Contrary to the findings of Williams et al. they are lower than those of evergreen species; this is also true when the construction cost of the non-storage compounds alone is considered. The values found for Ephedra are similar to the values reported in the literature on evergreen leaves. The maintenance costs do not show a significant variation in the deciduous leaves. They are higher than those known for evergreen leaves but somewhat lower than the values calculated for deciduous chaparral leaves.

Key words: Calorific energy - Storage compounds - Pistacia-Cotinus - Ephedra

In the Mediterranean type of vegetation, we find the different life forms of evergreen shrubs, considered to be drought tolerators, and of deciduous species, thought to be drought avoiders. It has been known that this description is too simplified (Ehleringer and Mooney 1983; Mooney 1983) inasmuch as deciduous shrubs also show important physiological properties similar to those of the evergreen species (Harley et al. 1987). Interestingly, upon calculating the con-

Offprint requests to: $\mathrm{U}$. Kull struction cost values for leaves of deciduous chaparral shrubs, Merino et al. $(1982,1984)$ found higher values for drought deciduous leaves than for evergreen leaves. Williams et al. (1987) confirmed these findings using their own method of calculation of the construction cost. Our earlier investigations of the seasonal trends of storage substances were confined to evergreen species (Diamantoglou and Kull 1982, 1988; Diamantoglou et al. 1989). In this paper, we report on the storage compounds and the energy content of two deciduous shrubs, Pistacia terebinthus and Cotinus coggygria, of the European mediterranean vegetation. According to the methods of Williams et al. (1987) and Merino et al. (1984) we calculated the construction and maintenance costs, which are compared with their data on chaparral shrubs and with the values calculated from our results on the evergreen stemmed mediterranean shrub Ephedra distachya (Diamantoglou et al. 1989).

\section{Materials and methods}

\section{Materials}

Leaves of deciduous species Cotinus coggygria Scop. (= Rhus cotinus L.) and Pistacia terebinthus L. (both Anacardiaceae) were taken from the shrubs of about $1,5 \mathrm{~m}$ height, growing on rather deep soil in openings of natural macchia-like vegetation near Malakassa (40 km N of Athens) on a NE-exposed slope of the lower part of the Parnes Mountain (about $380 \mathrm{~m} \mathrm{NN}$ ). Leaves from marked branches were taken (around $10^{00}$ a.m.) at monthly intervals starting in March when the leaves begin to sprout and later until the number of leaves on control shoots of similar shape had decreased by natural defoliation to about $25 \%$ of its initial value. The defoliation of the shrubs started from late August onwards. In September some of the leaves started to turn yellow and by October most of them were yellowish and senescent.

Climatic data of the harvesting period during 1985 are shown in Fig. 1. The dry summer period lasted for about 4 months.

\section{Methods}

Immediately after harvesting, one part of the leaves was put into plastic bags and dipped into boiling water for $10 \mathrm{~min}$. In the laboratory they were then dried in a ventilation oven at $60^{\circ} \mathrm{C}$. The other part was frozen immediately and stored at $-20^{\circ} \mathrm{C}$ for the investigations. 


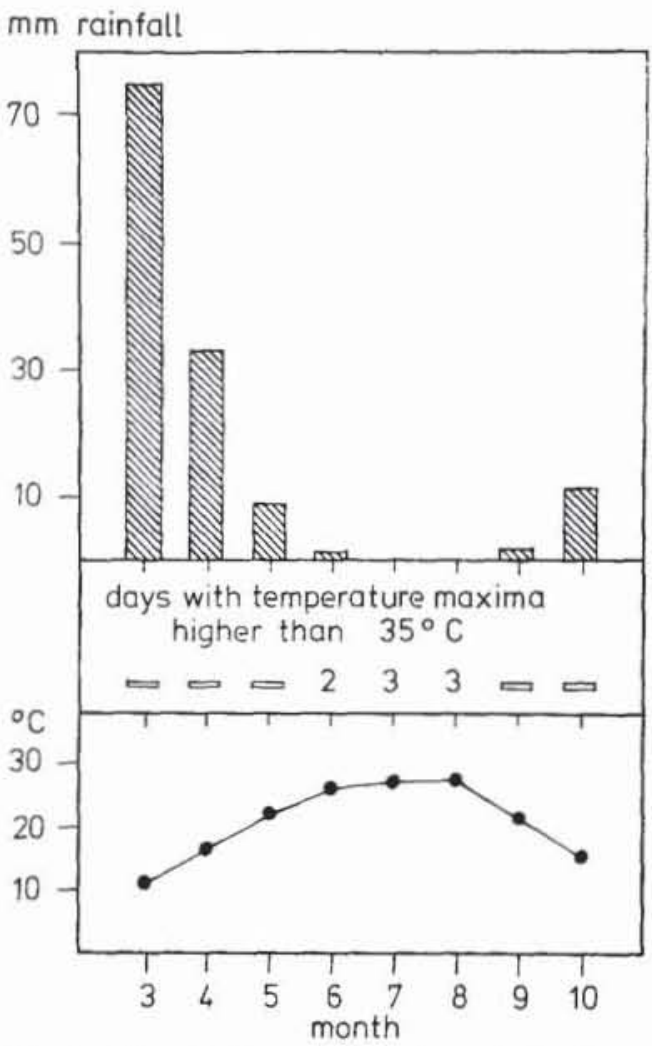

Fig. 1. Climatic data during the period of investigation. Top. monthly rainfall; bottom: monthly mean temperatures

Soluble sugars were analyzed by TLC, the total sugar content by the anthrone method (comp. Diamantoglou et al. 1989). The starch content was measured by the anthrone method of McCready et al. (1950). The total lipids were quantified according to the gravimetric method of Bligh and Dyer (1959). The total nitrogen content was measured by the method of Kjeldahl (1883), which was also used for the quantification of the protein- $\mathrm{N}$ after precipitation of the proteins with trichloroacetic acid (Diamantoglou and Kull 1988). The protein fraction was calculated by multiplying the protein- $\mathrm{N}$ content by 6,25 .

The content of crude fibre (including lignin) was determined after boiling the plant material with diluted sulfuric acid and diluted potassium hydroxide by the method described by Steubing (1965). The determination of chlorophyll content was performed also according to Steubing (1965).

From the estimation of the contents of the storage substances, their energy content was calculated and added up as described by Diamantoglou and Kull (1982). This energy value of the storage products is designated as ECS = energy content of storage substances.

The calorific total energy content (EGT-value, Pipp and Larcher 1988) of the leaves was measured by adiabatic calorimetry after a renewed drying of the plant powder in a desiccator. Calibration with benzoic acid: $26430 \mathrm{~kJ} / \mathrm{g}$; calorimeter: LGT-Waldkirch. The calorimetry was performed according to Larcher and Thomaser-Thin (1988; comp. also Pipp and Larcher 1987), but 35 bar oxygen pressure was used. Three or four replicates gave maximal deviations of $0,40 \%$ (coefficient of variation).

The ash content was determined gravimetrically after combustion of the plant material in a muffle furnace for $1,5 \mathrm{~h}$ at $500^{\circ} \mathrm{C}$. Based on the values obtained, the calculation of the energy equivalents was corrected and designated as the energy of ash-free substance (EAF-value).

The construction cost was calculated (as g glucose/g dry matter) according to the method of Willaims et al. (1987), using a value for growth efficiency $E_{G}=0.87$ (Penning de Vries et al. 1974, Penning de Vries 1975; McDermitt and Loomis 1981) and considering nitrate as the nitrogen source. The maintenance cost ( $g$ glucose/g dry matter $\times$ day) was estimated using the maintenance coefficients of and the method described by Merino et al. (1984). Since these authors gave a minimum and maximum value of the maintenance coefficients for proteins and for ions, the average values of these coefficients were used to calculate an average maintenance cost of the leaf substances.

The construction cost of the storage compounds was calculated using the values:

$1 \mathrm{~g}$ sugars equivalent to $1 \mathrm{~g}$ glucose

$1 \mathrm{~g}$ starch equivalent to $1,173 \mathrm{~g}$ glucose

$1 \mathrm{~g}$ lipid equivalent to $2,852 \mathrm{~g}$ glucose

(Larcher 1980; Hoffmann 1985). (A rather high content of resins in Pistacia may cause an error in the calculation of the construction cost of storage compounds; in Cotinus (and Ephedra) the error will be only small.) The difference between the total construction cost and the construction cost of the storage substances may be considered as the construction cost of the non-storage substances which mainly comprise the constructive components of the tissue (secondary plant substances are disregarded, this is thought to be a major source of inaccuracy). A fraction of the construction costs as defined by the equation (11) in Williams et al. (1987) represents the energy expenditure for $\mathrm{N}$-assimilation, for gaining the ions and the assimilation power not incorporated into the biomass. When the latter is (as done by Williams et al.) taken into consideration as the growth efficiency value $\mathrm{E}_{\mathrm{G}}$, it is possible to calculate this portion of the construction cost (which in the following is called the "energy expenditure") as the difference between the total construction cost and the energy of the ash free substance (EAF, expressed in the same unit of measure as $g$ glucose/g dry matter). The "energy expenditure" may give some additional understanding of the energy budget of the leaves.

\section{Results}

In both species, the relative water content of the leaves is decreasing from March (72-78\% of fresh weight) to July (35- $40 \%$ of fresh weight). Thereafter, it remains constant. The water budget is found to be stable also during the leaf senescence. Furthermore, the crude fibre content (Fig. 2) is increasing until July. The total $\mathrm{N}$ and protein $\mathrm{N}$ (Fig. 2) in the young leaves are normally declining during growth, reaching a steady state only in July/August and then start to decrease again. Beginning August the chlorophyll content (Fig. 2) also declines. From these data, one may conclude that the leaves undergo growth until June and that senescence starts in August.

The seasonal trends of the soluble sugars, starch and total lipids content are shown in Fig. 3. In both species, there is a distinct rise of sugar content during the drought period and a decline when senescence begins. The lipid con- 




Fig. 2. Crude fibre content, total- $\mathrm{N}$ content, protein- $\mathrm{N}$ content and chlorophyll content of leaves of Pistacia terebinthus and Cotinus coggygria $\mathrm{o}=$ Pistacia; $\Delta=$ Cotinus (also Figs. 3 and 4 )

tent rises in spring and then starts to diminish during the drought period. This effect is less distinct in Pistacia, perhaps because of a significant amount of resins in the lipid fraction. In spring, starch is considerably accumulated in the leaves of Cotinus, but not of Pistacia. In both species, only the sugars sucrose, glucose and fructose (the latter in smaller amounts) are accumulated. The amounts of the monosaccharides are found to be highest in August in both species. In Pistacia, the highest content of sucrose is also observed in August, but in Cotinus it is observed in June.

The ash content of the leaves increases during their lifetime (Fig. 4). The total calorific energy (CTE) values (Fig. 4) remain rather constant in Pistacia leaves and decrease somewhat in Cotinus. The energy content of the main storage products (ECS-value; Fig. 4) was estimated for Pistacia leaves to range from $1,6-3 \mathrm{~kJ} / \mathrm{g}$, for Cotinus leaves, values from $0,9-3,1 \mathrm{~kJ} / \mathrm{g}$ are found. In Pistacia, the storage substances are accumulating until August and start declining when the symptoms of senescence are visible. In Cotin$u s$, the accumulation is more pronounced during the leaf growth period and the highest value is found already in June. Less energy of storage substances and less total energy of the organic substance (energy of the ash-free dry matter, EAF, Fig. 4) are at disposal to the decomposers in the ecosystem by the defoliation of Cotinus then of Pistacia.

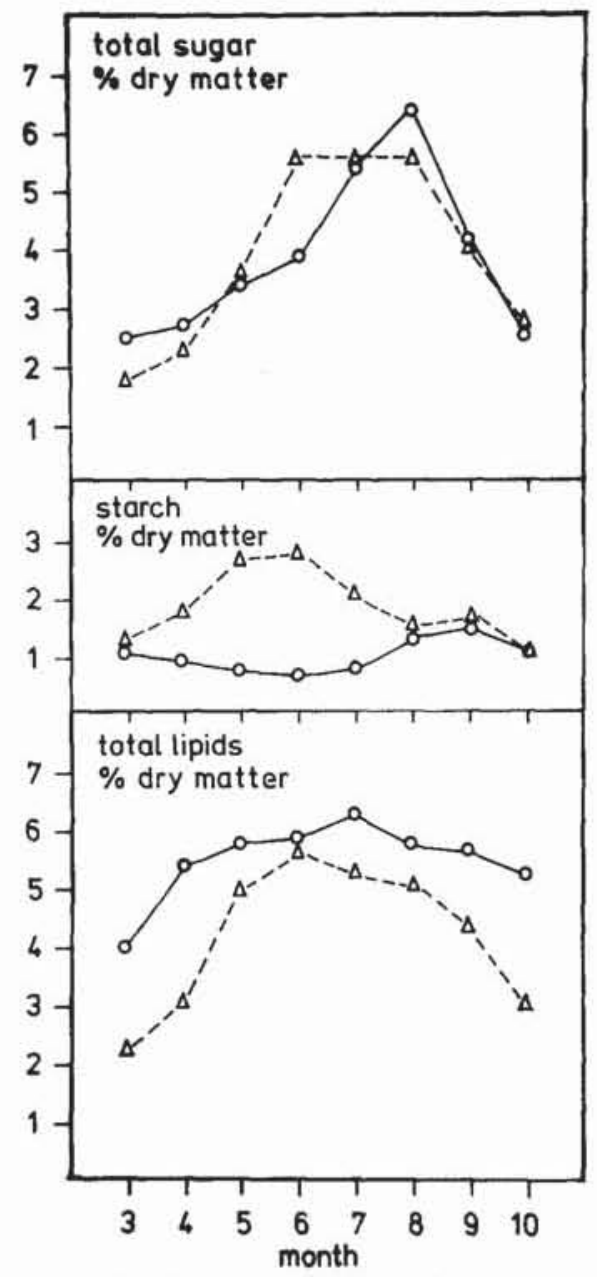

Fig. 3. Total sugar content, starch content and total lipids content of leaves of Pistacia terebinthus and Cotinus coggygria

From the data shown, the construction and maintenance costs as well as the energy expenditure of the leaves are calculated (Fig. 5). No complete set of data is available to allow for the calculation of these values according to the methods used in this paper regarding shrubs or trees with evergreen leaves of the European Mediterranean vegetation. For comparison, therefore, the corresponding values of the leafless evergreen chlorophyllous stemmed shrub Ephedra distachya were calculated from the data published by Diamantoglou et al. (1989). They are also shown in Fig. 5. The construction costs of the deciduous leaves of both species are very similar; the values for Ephedra are significantly higher. In Cotinus leaves the construction cost decreases with increasing leaf age, while in the case of Pistacia leaves, it is relatively constant throughout their livespan. The same is true for the evergreen twigs of Ephedra. The construction costs of the non-storage substances behave similarly but increase in the senescing leaves. In Ephedra, the construction cost of the non-storage substances is lower during the late growth period and higher from autumn to March.

The average maintenance costs of the deciduous leaves show no significant variations. In Ephedra, maintenance costs decline throughout the late drought period as a result of the decrease of lipid and protein components (comp. 


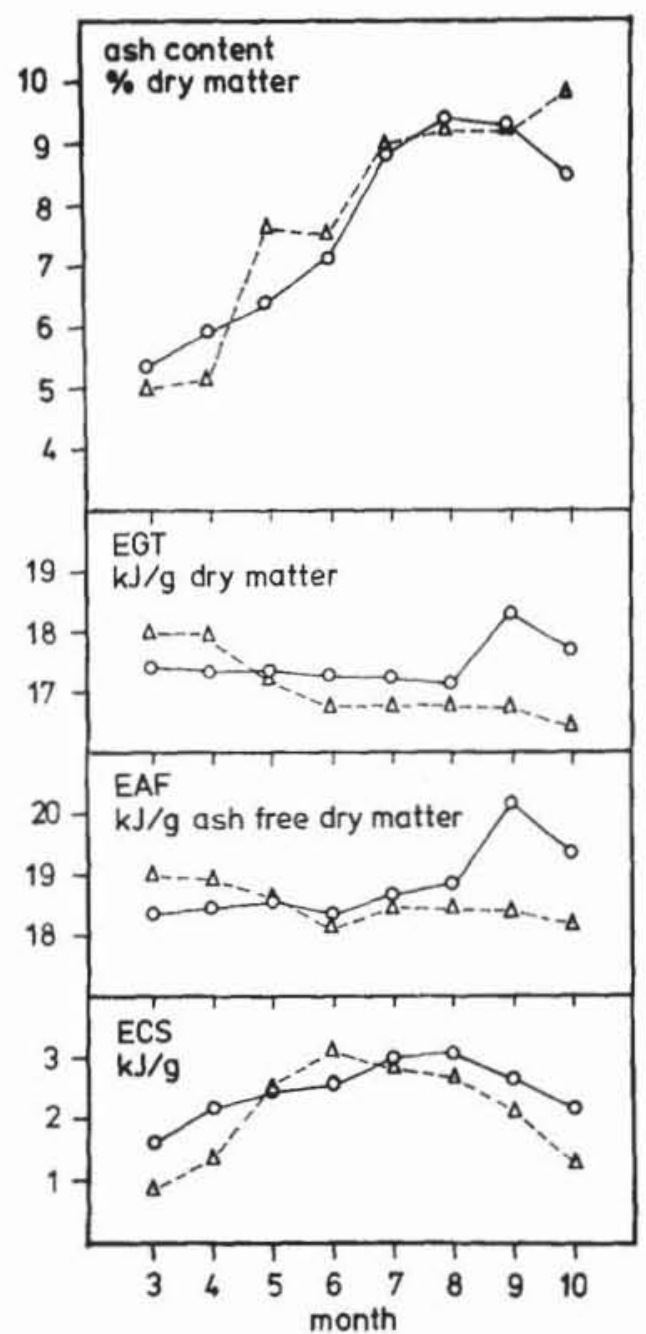

Fig. 4. Ash content, calorific total energy (EGT), energy content of the ash-free dry matter (EAF) and energy content of the storage substances (ECS) of leaves of Pistacia terebinthus and Cotinus coggygria

Diamantoglou et al. 1989). The average maintenance costs in the deciduous leaves are higher only by a small fraction than in evergreen Ephedra twigs.

The energy expenditure values calculated from the construction costs according to the method described decline in the leaves of the deciduous shrubs but remain rather constant in the Ephedra-twigs.

\section{Discussion}

The results of our investigation of the two deciduous mediterranean shrubs may be compared with the data on evergreen shrubs, especially Pistacia lentiscus, of the Greek phrygana vegetation near Athens (summarized in Diamantoglou and Kull 1982, 1988) and also the results reported on chaparral plants of California (Merino et al. 1984).

The water content of the mature leaves of Pistacia terebinthus and Cotinus is similar to that of the evergreen Pistacia lentiscus at their specific natural stands, which have different water-supplies. Under identical stress conditions, the transpiration rates of Pistacia lentiscus are lower than

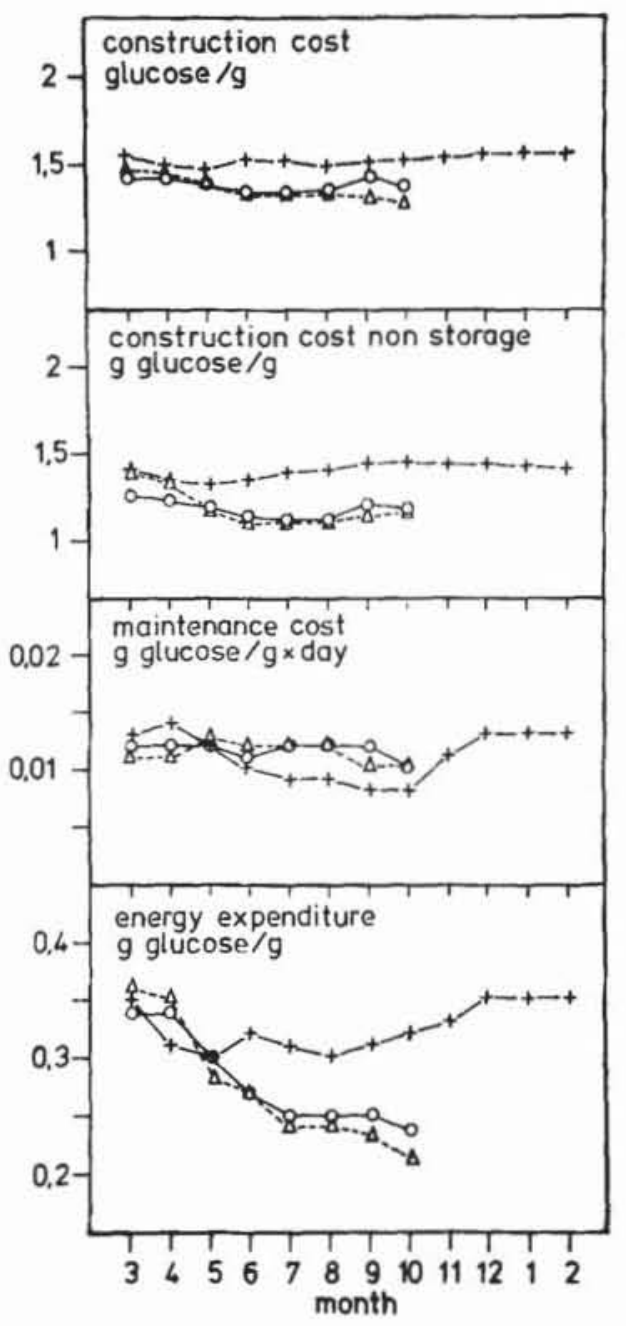

Fig. 5. Construction costs (as g glucose/g dry matter), construction costs of the non-storage substances, maintenance costs (as g glucose/g dry matter $x$ day) and energy expenditure (as $g$ glucose/g dry matter) of the leaves of Pistacia terebinthus and Cotinus coggygria during their lifespans and of green shoots of Ephedra distachya during one year, $\mathrm{O}=$ Pistacia $\Delta=$ Cotinus; $+=$ Ephedra

of Pistacia terebinthus (Mooney 1969). The crude fibre content in our deciduous leaves shows values similar to those found in leaves of diverse evergreen species. Also, the chlorophyll content is in the same range as found for the evergreen species. Interestingly, the total- $\mathrm{N}$ and protein- $\mathrm{N}$ contents also show similar values as in the evergreen species. The decline of the $\mathrm{N}$-content in senescing leaves is probably due to an export of $\mathrm{N}$-compounds; the final concentration in the dying leaves of $3-5 \mathrm{mg} / \mathrm{g}$ dry matter is in the same range as found for evergreen leaves.

The accumulation of soluble sugars during the summer drought period is more distinct in the deciduous species than in the leaves of $P$. lentiscus (Diamantoglou and Meletiou-Christou 1979; Diamantoglou and Kull 1982). A rise of the osmotic pressure during the summer period in the leaves of all three Anacardiaceae is by and large parallel to the total sugar content. Therefore, it is thought to be an active increase due to drought avoidance, as discussed by Kull and Breckle (1972).

The ash-content of the leaves in our deciduous species is in the range listed by Pipp and Larcher (1988) for leaves 
of such shrubs in the Mediterranean climate. The values are higher than those measured in Lepechinia (Merino et al. 1984). The calorific total energy (EGT) - values are in accordance with the data of Pipp and Larcher (1988) on $\mathrm{Ru}$ tanae.

The construction costs of the leaves of $P$. terebinthus and Cotimus are significantly lower than those calculated by Williams et al. (1987) for the two drought deciduous chaparral species. The earlier publications of data on deciduous leaves, in most cases, originate from annuals and report an average of about 1,3 (Hunt and Loomis 1979). This is in agreement with our data on the fully expanded leaves. The decrease with age of the construction costs of deciduous leaves is much more distinct in the chaparral shrubs than in our species; its possible causes are discussed by Williams et al. (1987). The construction cost values obtained for the chlorophyllous stemmed evergreen shrub Ephedra correspond with the costs for the evergreen Heteromeles leaves found by Williams et al. (1987) and are nearly in the same range as those found for Pinus taeda (Chung and Barnes 1977).

The green tissues of Ephedra are somewhat more expensive to construct than the deciduous leaves of $P$. terebinthus and Cotinus despite of a very similar protein content. This is also true when the construction cost of the non-storage compounds alone is considered. The higher construction cost found for the assimilating evergreen tissues agrees with earlier findings, which are discussed in detail by Chabot and Hicks (1982). However, we have our reservations, because no comparable data are available on evergreen true leaves of European Mediterranean species. Contrary to our findings, Merino et al. (1984) reported that the leaves of the deciduous chaparral species are more expensive to grow that those of the evergreen Heteromeles.

The maintenance cost values obtained for Ephedra are well comparable to the values calculated by Merino et al. (1984) for the Heteromeles leaves. In contrast, the maintenance cost values found for the European deciduous species are lower than those found by Merino et al. for the chaparral deciduous species. In Ephedra, they decrease somewhat during the late growth period due to the decline of lipid and protein contents. The maintenance costs of the deciduous leaves are higher than those found for evergreen tissues, but the difference is not as pronounced as found by Merino et al. (1984). The observed differences in maintenance costs are in agreement with the conclusion of Bloom et al. (1985) that the total maintenance costs may not vary greatly among tissues and species considering their different lifespans.

As Schulze (1982) and Schulze and Chapin (1987) stated, there are different strategies of the different life forms and species, which are correlated with variations in the efficiency of metabolic processes, ion-uptake, N-gain, -storage and -utilization and different adaptibilities of these processes to stress factors. Therefore, it could be expected that the three species investigated would have different energy expenditure values which decrease during the lifespan of the deciduous leaves and which remain obviously stable in the Ephedra shoots (which have an average lifespan of about 2-3 years) during the period of investigation.

In $P$. lentiscus and Cotinus, leaves are produced in early spring and retained until September. Because the lifespan of the leaves should be related to a balance between the construction costs and the benefits, the leaves must live productively relatively long throughout the drought period. This could be attained by a stable plant water status caused by a good stomatal control during the onset of drought at the natural stands; in contrast to the findings of Poole and Miller (1975) on Californian chaparral species. The data of Harley et al. (1987) on photosynthesis and water status of the drought deciduous Cistus salvifolius leaves allow us to suggest a similar behavior of the leaves of $P$. terebinthus and Cotinus, which on the basis of their anatomy, are somewhat more sclerophyllous than those of Cistus.

The strategy of the accumulation of storage substances in the leaves of Cotinus and P. terbinthus seems to be somewhat different. In Cotinus, there is an early and considerable increase of storage compounds, whilst in $P$. terebinthus the accumulation is continuous and more uniform until August. This suggests a stabilization of the plant water status in Cotinus by prolonged periods of stomata closure compared to $P$. terebinthus.

As Harley et al. (1987) pointed out, there is a continuum of response from sclerophyllous evergreen to drought deciduous shrubs. Based on their findings on Cistus, from our data on Pistacia terebinthus and Cotinus, it may be concluded that these species show also intermediary characteristics between sclerophyllous drought tolerators and deciduous drought avoiders.

Long lived assimilating tissues have to invest more energy in their defense against herbivory. The protective mechanisms vary in different species which may be a possible explanation for the different metabolic costs. Hitherto, this has not been taken into consideration in calculating construction costs. Ephedra synthesizes ephedrine, which is efficient already in low concentrations and therefore, not very expensive. Fresh leaves with low sclerophylly frequently found in the deciduous species of the mediterranean type vegetations are consumed by herbivores preferably. The leaves of Pistacia and Cotinus show a rather high crude fibre and a low protein- $\mathrm{N}$ content. Furthermore, Anacardiaceae are well known for the production of substances acting as allergenes. Perhaps the higher construction costs of the deciduous Californian chaparral species, Diplacus and Lepechinia (Merino et al. 1984; Williams et al. 1987) are partly due to the production of higher amounts of more expensive secondary substances effective as protectives. In conclusion, there seem to be different strategies of semidrought-deciduous shrub species in the Mediterranean type of vegetation in relation to drought resistance and defense against herbivory.

Acknowledgements. Thanks are due to Mrs. U. Friederich for valuable experimental help, Mrs. Dipl. Biol. A. Herbig for discussions and Mrs. B. Solis-Schreiter for correction of the English. Part of the research was supported by the DFG (SFB 230).

\section{References}

Bligh EG, Dyer WJ (1959) A rapid method of total lipid extraction and purification. Canad J Biochem Physiol 37:911-917

Bloom AJ, Chapin III FS, Mooney HA (1985) Resource limitation in plants - an economic analogy. Ann Rev Ecol Syst $16: 363-392$

Chabot BF, Hicks DJ (1982) The ecology of leaf life span. Ann Rev Ecol Syst 13:229-259

Chung HH, Barnes RL (1977) Photosynthate allocation in Pimus taeda. I Substrate requirements for synthesis of shoot biomass. Can J For Res 7:106-111 
Diamantoglou S, Meletiou-Christou MS (1979) Kohlenhydratgehalte und osmotische Verhältnisse bei Blättern und Rinden von Pistacia lentiscus, Pistacia terebinthus und Pistacia vera im Jahresgang. Flora 169:168-176

Diamantoglou S, Kull U (1982) Die Jahresperiodik der Fettspeicherung und ihre Beziehung zum Kohlenhydratstoffwechsel bei immergrünen mediterranen Holzpflanzen. Acta Oecol/Oecol Plant 3 (17): $231-248$

Diamantoglou S, Kull U (1988) Der Stickstoffhaushalt immergrüner mediterraner Hartlaubblätter. Flora 180:377-390

Diamantoglou S, Rhizopoulou S, Herbig A, Kull U (1989) Seasonal trends in energy content and storage substances in the mediterranean shrub Ephedra. Acta Oecol/Oecol Plant 10:(in press)

Ehleringer J, Mooney HA (1983) Productivity of desert and mediterranean climate plants. In: Lange OL, Nobel PS, Osmond $\mathrm{CB}$, Ziegler H (eds) Physiological plant ecology IV (Encyclopedia of plant physiology, NS, vol 12 D). Springer, Berlin Heidelberg New York, pp 205-231

Harley PC, Tenhunen JD, Beyschlag W, Lange OL (1987) Seasonal changes in net photosynthesis rates and photosynthetic capacity in leaves of Cistus salvifolius, a European mediterranean semideciduous shrub. Oecologia $74: 380-388$

Hoffmann P (1985) Ecophysiological aspects of biomass production in higher plants. Photosynth Res 7:3-17

Hunt WF, Loomis RS (1979) Respiration modeling and hypothesis testing with dynamic model of sugar beet growth. Ann Bot $44: 5-17$

Kjeldahl J (1883) Über die Stickstoffbestimmung. Z Analyt Chem $22: 366-370$

Kull U, Breckle SW (1972) Osmotische Verhältnisse und Zuckergehalte im Jahresgang bei Bäumen Ost-Afghanistans. II Cercis griffithii und Pistacia cabulica. Flora 161:586-603

Larcher W (1980) Physiological plant ecology. Springer, Berlin Heidelberg New York

Larcher W, Thomaser-Thin W (1988) Seasonal changes in energy content and storage patterns of mediterranean sclerophylls in a northernmost habitat. Acta Oecol/Oecol Plant 9:271-283

McCready RM, Guggolz J, Silviera V, Owens MS (1950) Determination of starch and amylose in vegetables. Analyt Chem 22:1156-1158

McDermitt DK, Loomis RS (1981) Elemental composition of biomass and its relation to energy content, growth efficiency and growth yield. Ann Bot 48:275-290

Merino J, Field C, Mooney HA (1982) Construction and mainte- nance costs of mediterranean-climate evergreen and deciduous leaves. I Growth and $\mathrm{CO}_{2}$ exchange analysis. Oecologia $53: 208-213$

Merino J, Field C, Mooney HA (1984) Construction and maintenance costs of mediterranean-climate evergreen and deciduous leaves. II Biochemical pathway analysis. Acta Oecol/Oecol Plant 5 (19):211-229

Mooney HA (1969) Dark respiration of related evergreen and deciduous mediterranean plants during induced drought. Bull Torrey Bot Club 96:530-555

Mooney HA (1983) Carbon-gaining capacity and allocation patterns of mediterranean-climate plants. In: Kruger FJ, Mitchell DT, Jarvis JUM, Mediterranean-type ecosystems. The role of nutrients. Springer, Berlin Heidelberg New York, pp 103-119

Penning de Vries FWT (1975) The cost of maintenance processes in plant cell. Ann Bot 39:77-92

Penning de Vries FWT, Brunsting AHM, Laar HH van (1974) Products, requirements and efficiency of biosynthesis: a quantiative approach. J Theor Biol 45:339-377

Pipp E, Larcher W (1987) Energiegehalte pflanzlicher Substanz. I Erfassung und Verarbeitung des Datenmaterials. Sitz ber Österr Akad Wiss Math nat Kl Abt I 196:37-66

Pipp E, Larcher W (1988) Energiegehalte pflanzlicher Substanz. II Ergebnisse der Datenverarbeitung. Sitz ber Österr Akad Wiss Math nat K1 Abt I 197 (in press)

Poole DK, Miller PC (1975) Water reiations of selected species of chaparral and coastal sage communities. Ecology $56: 1118-1125$

Schulze ED (1982) Plant life forms and their carbon, water and nutrient relations. In: Lange OL, Nobel PS, Osmond CB, Ziegler H (eds) Physiological plant ecology II (Encyclopedia of plant physiology NS, vol 12 B) Springer, Berlin Heidelberg New York, pp 615-676

Schulze ED, Chapin II FS (1987) Plant spezialisation to environments of different source availability. In: Schulze ED, Zwölfer $\mathrm{H}$ (eds) Potentials and limitations of ecosystem analysis, Ecol Studies 61, Springer, Berlin Heidelberg New York, pp 120-147

Steubling L (1965) Pflanzenökologisches Praktikum. Parey, Hamburg Berlin

Williams K, Percival F, Merino J, Mooney HA (1987) Estimation of tissue construction cost from heat of combustion and organic nitrogen content. Plant Cell Environm 10:725-734

Submitted March 20,1989/Accepted July 29, 1989 